\title{
RESEÑA. RETOS PARA LA FORMACIÓN INICIAL. DESDE LAS MIRADAS Y VOCES DE DOCENTES EN ACTIVO
}

\section{REVIEW. RETOS PARA LA FORMACIÓN INICIAL. DESDE LAS MIRADAS Y VOCES DE DOCENTES EN ACTIVO}

\author{
Carmen Moguel González \\ Universidad de Cádiz \\ https://orcid.org/0000-0002-4941-7611 \\ mcarmen.moguel@uca.es
}

Recibido: 01/04/2020 Revisado: 05/05/2020 Aceptado: 10//04/2020

Autor: Víctor Amar (Coord.)

Editorial: Octaedro: Barcelona

RETOS PARA

Año: 202

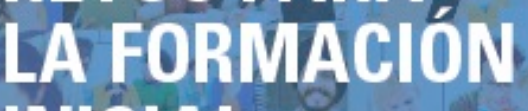
INICIAL

DESDE

LAS $=$ MIRADAS

YLAS VOCES

DEDOCENTES

ENACTIVO

VÍCTOR AMAR (COORD.)

Octaedro 4

Cómo citar este artículo: Moguel, C. (2020). Reseña. "Retos para la formación inicial desde las miradas y voces de docentes en activo". Hachetetepé. Revista científica en Educación y Comunicación, (20), 108109. doi: http://doi.org/10.25267/Hachetetepe.2020.i20.13

Recién salido del horno. Un horno simbólico, queremos decir. El libro Retos para la formación inicial. Desde las miradas y las voces de docentes en activo es la esperada tercera entregada de la trilogía "Miradas y voces de docentes". Pues, en esta ocasión, le toca al turno a aquellas personas que desde su responsabilidad toman a su cargo el hecho de llevar una clase. Y solo saben lo complejo de este ejercicio profesional y personal, 


\section{Hachetetepé. Revista científica de Educación y Comunicación}

$\mathrm{N}^{\mathrm{o}}, 20,108-109,2020$

aquellas personas que han tenido a nuestro cargo este quehacer (o son sensibles con la profesión docente). No es fácil ser maestro o maestra, en ningún ciclo formativo. La educación es un ejercicio que requiere desde cualificación a empatía, desde ser buena persona a saber sonreír, desde tener capacidad para trabajar con tus compañeros a saber llevar una tutoría con los familiares, desde atender y dar respuesta a la normativa educativa hasta estar en plena forma física y mental, aprendiendo continuamente con cursos o autoformándose...

Pues bien, de una u otra forma, el lector del presente libro encontrará dibujada o esbozado estas singularidades que atribuimos al docente en activo. El siglo XXI ha cambiado la realidad, no solo del aula sino de la cohabitación en ella y fuera de ella. No es fácil ser maestro o maestra, requiere mucha responsabilidad y cuando hablan estos profesionales intuimos detrás de sus voces un sinnúmero de zozobras que no es que les perturben sino que hacen que saquen fuerzas de flaqueza. Ser maestro o maestra es un reto; tal vez, un desafío diario que exige el deseo de no defraudar a nadie pero, sobre todo, no olvidar que trabajan y se deben a niños y niñas.

Por ello, estamos ante nueve miradas que tienen voz propia. Un libro que completa la visión tripartida del pasado (docentes jubilados), del futuro (aquellos que siendo alumnos pronto se incorporarán a la dinámica laboral) y ahora tenemos la entrega del presente. Un proyecto que se inició hace años atrás. Un trabajo en el cual se aglutinaron estilos de narrativas que ponen el foco en realidades inspiradas en la experiencia. Organizado por capítulos el grito de serenidad a una profesión fascinante se deja ver desde el principio al final. Son puntos de vistas que llenan la avidez del lector que quiere ser partícipe de lo narrado. De este modo, agradecemos esta opción metodológica que es hábil en dar respuesta a la intención: compartir desde la generosidad de una profesión que tiene tanto de vocación y de anhelo de facilitarle la vida a los demás.

De nuevo, la editorial barcelonesa de Octaedro avala el producto. Una vez más, tenemos la oportunidad de ponerle tono a la voz de los entrevistados. Sin género de dudas, este grupo de profesorado de la Universidad de Cádiz, concluyen un periplo iniciado hace un lustro. Y hemos de desear que el proyecto se ha de continuar, al menos, desde otra perspectiva.

Estamos ante una vocación que no es de princesas o príncipes, que nos permite embarcarnos en un viaje para entender la escuela o, tal vez, somos testigos del viaje de una maestra que tiene como meta encontrar a María y sus puntadas de luz. Y cual Cid educador, desde la más tierna infancia nos muestra su increíble sonrisa. Como un juego de palabras hemos intentado dar cobertura a los diferentes títulos del libro. Es más que un simple juego, se trata de una invitación formal y por ello, por favor, léanlo con atención. Los autores junto con los informantes, nos dan una lección magistral y de vida, de profesionalidad y de talante...

Amar, V. (Coord.) Retos para la formación inicial desde las miradas y voces de docentes en activo. Barcelona: Octaedro 